\title{
The Rate of Virus Spread in New Potato Cultivars in the North of Poland
}

\author{
Sławomir Wróbel ${ }^{1}$ \\ Received: 10 March 2015 / Accepted: 19 November 2015 / \\ Published online: 6 January 2016 \\ (C) The Author(s) 2016. This article is published with open access at Springerlink.com
}

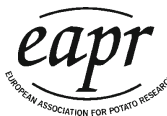

\begin{abstract}
The aim of this research was to assess the rate of increase in the level of tuber infection by PVY, PVM, and PLRV during three consecutive years of multiplication in the field for 17 new cultivars registered in Poland in 2009-2011 and for two cultivars not listed in the registry but popularly cultivated. The research was conducted in Bonin near Koszalin (north-western Poland) in 2010 2013. Tuber infection was assessed using DAS ELISA in a grow-out test in the winter-spring period. Among the 19 cultivars examined, eight had high resistance to PVY (above grade 8 on a scale of 1-9); during the 3 -year research period, they were not infected. Also, cv. Gawin seemed more resistant than previously assumed. In contrast, cvs. Hermes and Sylvana, which were rated in the Netherlands as quite resistant, were clearly very susceptible (grade 3-4) in Polish conditions, as within 2 years $100 \%$ of tubers were infected with this virus. The greatest susceptibility to PVM was shown by cvs. Danuta and Stasia, 50\% of which were infected, despite moderate exposure to the virus. Cultivars Zenia, Etiuda, Jubilat, and Viviana appeared very resistant to PVM as the number of infected tubers did not exceed 5\%. PVM was not detected in the tubers of cvs. Bursztyn, Gustaw, and Legenda, which confirmed that these cultivars possess the Rm gene. Not all cultivars regarded susceptible (grade 3-4) to PLRV were infected. The virus was not found in tubers of cv. Bursztyn, while in cv. Hermes, assessed in the Netherlands as being quite resistant, almost $40 \%$ of tubers were infected.
\end{abstract}

Keywords Aphids $\cdot$ PLRV PVM PVY

Sławomir Wróbel

wrobel@ziemniak-bonin.pl

1 Department of Potato Protection and Seed Science in Bonin, Plant Breeding and Acclimatization Institute, National Research Institute, 76-009Bonin 3, Zachodniopomorskie, Poland 


\section{Introduction}

In seed potato production, the greatest harm is caused by viruses that infect tubers and decrease the quality and quantity of the harvest (Whitworth et al. 2006; Rahman and Akanda 2010; Rahman et al. 2010; Islam et al. 2014) and thus constitute the main cause of seed material degeneration. The potato viruses considered as the most important ones, not only in Poland, are Potato virus $Y$ (PVY), Potato virus $M$ (PVM), and Potato leafroll virus (PLRV). They all are transmitted by aphids, but only PLRV is transmitted in a persistent way. A characteristic feature of nonpersistent transmission (PVY, PVM) is that viral particles can be acquired and then transmitted in seconds by the probing aphid (Kostiw 1987). In recent years, the PLRV threat to potato crops in Poland has diminished (Kostiw and Sekrecka 2009; Kostiw 2011; Wróbel and Wassik 2013), though, in the mid-1970s, it was considered to be the most important virus after PVY (Gabriel 1989). Meanwhile, the importance of PVY has grown because of changes in the virus strains' populations (Chrzanowska 2004) as well as a significant increase in the share of susceptible cultivar production (Kostiw 2013a; Wróbel and Wassik 2013). Currently, PVY is the fifth on the list of the most economically important plant viruses around the world (Scholthof et al. 2011). It belongs to the family Potyviridae and has been classified into five strain groups of varied immunological characteristics: $\mathrm{PVY}^{\mathrm{O}}, \mathrm{PVY}^{\mathrm{N}}$, $\mathrm{PVY}^{\mathrm{C}}, \mathrm{PVY}^{\mathrm{Z}}, \mathrm{PVY}^{\mathrm{E}}$ (Chikh Ali et al. 2013). Genomes of these strains additionally tend to re-combine easily which leads to the formation of recombinants of different biological and immunological features, e.g., PVY ${ }^{\mathrm{NTN}-\mathrm{NW}}$ (Chikh Ali et al. 2010). At present in Poland, there are mainly isolates of $\mathrm{PVY}^{\mathrm{N}-\mathrm{Wi}}$ and PVY $^{\text {NTN }}$ (Zimnoch-Guzowska et al. 2013). In 2008, about $65 \%$ of the entire PVY population was constituted by the PVY ${ }^{\mathrm{NTN}}$ strain and $30 \%$ by $\mathrm{PVY}^{\mathrm{N}-\mathrm{Wi}}$. Two years later, the ratio reversed and the share of $\mathrm{PVY}^{\mathrm{NTN}}$ was only $14 \%$, and of $\mathrm{PVY}^{\mathrm{N}-\mathrm{Wi}}$ -just over $60 \%$. In general, one can say that nearly $90 \%$ of the overall PVY population is represented by the $\mathrm{PVY}^{\mathrm{N}}$ strain which dominates also in other European countries (Dědič et al. 2008; Van der Vlugt et al. 2008; Lindner 2008; Rolot and Steyer 2008). Once frequent, $\mathrm{PVY}^{\mathrm{O}}$ has been very rare in Poland over the past few years (Kaczmarek et al. 1998; Chrzanowska 2009; Zimnoch-Guzowska et al. 2013). However, in some countries, like for instance the USA or Canada, it is of more significance than in Europe (Bai et al. 2010; Gray et al. 2013).

Aphids accidentally flying over potato plantations in search for a host plant, but for whom potatoes are no host plants (i.e., non-potato-colonizing aphids), have significance in non-permanent virus vectoring, including PVY in the initial stage of the growth season (Kostiw and Robak 2008, 2009, 2010). It is connected to the facts that in Poland's natural conditions their flights take place earlier (about 2 weeks) than those of potato-colonizing aphids and that they have a higher flight activity. Some nonpotato-colonizing aphid species are capable of transmitting non-permanent viruses (Sigvald 1984; Kostiw 1987; Kostiw and Robak 2002).

PVM, like PLRV, is less common now than it was 30 years ago (Zagórska and Chrzanowska 2007). According to Chrzanowska et al. (2011), it is encountered in approximately $10 \%$ of all assessed samples, but most PVM strains found in Poland are rather weak, which under field conditions give weak symptoms on potato plants. Because protecting against virus infection is difficult and aphid control is ineffective 
(Milošević 1996; Wróbel 2014a), cultivar resistance has acquired a greater importance in potato seed production (Styszko 1993).

The assessment of the resistance of registered potato cultivars to PVY and PLRV, despite the simplified procedure in use since 2004 (Michalak 2006), accurately characterizes cultivars resistant to viruses and singles out those with extreme resistance. The assessment, using a 9-point scale (Chrzanowska et al. 2011), is comparatively precise in determining resistance, yet a substantial difference in the increasing infestation of cultivars of similar resistance levels with particular viruses under field conditions can be seen. Moreover, foreign cultivars, despite being assigned high field resistance for particular viruses in their countries of origin, prove to be much more susceptible to infection in Polish conditions (Świeżyński et al. 2001). There are also cultivars that, when multiplied up to a larger scale under production conditions, prove to be more susceptible than previously assessed (Wróbel and Turska 2005; Wróbel 2012).

Many years ago, Poland was divided into spheres (regions) which are more or less adequate for potato seed production. It is connected with the pressure of aphids-virus vectors. These spheres have been in use until present and so potato seed production is centred in the north of the country due to the most favorable conditions. The assessment of cultivar resistance is of a huge importance in terms of regionalization of crops and suggestions for the exchange of seed potatoes. High resistance of cultivars that has been observed (no virus infection) in spite of a large number of infection sources is a signal that in production conditions where there are not so many sources of the virus, exchanged seed will degenerate more slowly than in the case of susceptible cultivars.

The aim of this research was to assess 17 potato cultivars registered during 20092011 and two relatively popular ones that are not registered, with respect to the rate of tuber infection with PVY, PVM, and PLRV in the years following multiplication, in field conditions in the north of Poland.

\section{Material and Methods}

The research was carried out during 2010-2013 in the village of Bonin, near the city of Koszalin, in north-western Poland $\left(54^{\circ} 09^{\prime} \mathrm{N}, 16^{\circ} 15^{\prime} \mathrm{E}\right)$. Nineteen potato cultivars were examined, having known resistance levels to PVY and PLRV ranging from very susceptible to highly resistant according to the assessment by the Research Centre for Cultivar Testing (Polish abbreviation COBORU). The same cultivars were also tested for PVM. However, resistance levels for this virus were known only for four of the investigated cultivars. Based on the obtained results, these cultivars were grouped according to their resistance to PVM using the PVM-resistance classification system previously proposed by Wróbel (2012). In the last week of April of the first year, 100 seed tubers of each cultivar, obtained directly from a breeder, were planted in the field. To ensure the healthiness of the seed potatoes, they were assessed using DAS ELISA in a grow-out test prior to planting according to the procedure described by Wróbel (2014b). Polyclonal antibodies by Neogen Europe Ltd. (PVY - cat nr. 1142-07; PVM - cat nr. 1042-07; PLRV - cat nr. 1038-07) and microtiter F-type plates Grainer Bio-One (cat nr. 655101) were used. 4-Nitrophenyl phosphate disodium salt hexahydrate was used as a substrate, which in a positive reaction becomes yellow. Reading 
was made after 60-180 min (when absorbance value for the positive control exceeded 1.3) using the Dynatech MR 5000 plate reader, taking for a certain positive reaction an absorbance value above 0.2. If the results were uncertain (absorbance in range 0.1-0.2) DAS ELISA was repeated. To perform the test, a sample containing an eye was collected from each tuber and planted in a glasshouse in a pot filled with peat substrate, while the remaining part of the tuber was subsequently planted in the field. Each plot had 100 potato plants $(50$ plants per row $\times 2$ rows, each planted in an area of $0.75 \times 0.3 \mathrm{~m}$ ). Additionally, 50 potato plants that were secondarily PVY, PVM, and PLRV infected were planted near each plot to provide the source of infection. These plants originated from a seed of one susceptible cultivar which had been planted in the field for many years and acquired viruses in a natural way. According to random samples on these infector plants, each plant was infected with PVY, about half of them were also infected with PVM, and about a third was infected with PLRV. Application of these infection sources created a viral pressure that was many times higher than in production conditions. Moreover, the assessed cultivars became infected during the years of research comprising at the same time new sources of infection. The format of the experiment was as follows: the first row was planted with virus sources (infector plants), followed by four rows with tested cultivars (two rows with 50 plants per row for a single cultivar), followed by a single row (50 plants) with virus sources. Such a format was repeated for all assessed cultivars. This arrangement was intended to increase virus pressure by providing a nearby inoculum source.

Every year during the period from May 1 to August 31, the flight activity of aphids was monitored. For this purpose, two yellow water traps (round, plastic yellow dishes (bowls), $23 \mathrm{~cm}$ in diameter and $10 \mathrm{~cm}$ high half-filled with clean water with no detergent added) were set up in the vicinity of the experimental plots, positioned on a black fallow plot with dimensions of $20 \times 20 \mathrm{~m}$, the aphid plot. Potatoes were planted around the aphid plot at $3 \mathrm{~m}$ from the edge. The traps were emptied every day, and the aphid species were determined. Keys by Müller (1966) and Taylor et al. (1980) were used. Depending on the year of the research, the aphid plot was located at most $30 \mathrm{~m}$ away from the plots with tested cultivars. Additionally, every 10 days, aphid colonization was investigated using the "100 leaves" method using the potato plants growing around the aphid plot. Observations were made by randomly collecting 100 individual leaves from the middle part of the plants and counting all aphids and subdividing them into species. Observations were made 10 times during the growing season (1000 leaves in total).

During the growth season, aphids were not controlled, only chemical protection against fungal diseases was provided. One treatment per season (2010-July 8, 2011-June 16, 2012 - June 30, 2013-June 27) was carried out against Colorado potato beetle using Nomolt $150 \mathrm{SC}$ (active ingredient teflubenzuron) at a dose of $0.251 \mathrm{ha}^{-1}$. At the end of the growing season, one tuber from each plant was collected to assess virus infection. This amounted to 100 tubers per cultivar in total after the first year of the study. In subsequent years, the number of tubers gradually decreased because of rotting during storage. Virus infection of the collected samples was assessed using DAS ELISA in a grow-out test in the spring of the following year in an analogous way to that described above. From each tuber, a fragment containing one eye was removed and planted in the glasshouse in order to assess virus infection while the remaining part of the tuber was planted 
later directly in the field. The procedure was repeated in each year for all the assessed cultivars. Such practice allowed one to assess each plant from the start of the experiment and monitor the healthiness of its progeny tubers in subsequent years of the research. Infection level was defined as a percentage of infected tubers.

\section{Results}

\section{Aphids}

The potato-colonizing group of aphids found was composed of two species only-Myzus persicae and Aphis nasturtii. During the study period, a very small number-91.5 specimens of potato-colonizing aphids-were collected in the yellow water traps (Table 1). At the same time a large number-2194 aphidswas recorded on plants (Table 1). Among the trapped colonizing aphids, the dominant species was $M$. persicae. The non-potato-colonizing aphids were very frequent in traps, (1975.5 aphids per trap-Table 1), but on plants only few (29 aphids) were recorded (Table 1). An especially high number of aphids from both groups was collected in 2012, when their number equalled to about half of the number recorded for all four seasons. Among the trapped non-potato-colonizing aphids, the most numerous were Aphis fabae, Hayhurstia atriplicis, and Cavariella aegopodii; however, most specimens of these species were recorded during one season only (2012 for A. fabae and C. aegopodii and 2013 for $H$. atriplicis), and only $H$. atriplicis was recorded during all seasons of investigation (Table 2). Less numerous but more constantly recorded during all seasons of investigation were Brevicoryne brassicae, Cryptomyzus galeopsidis, and Rhopalosiphum padi (Table 2). The flights of non-potato-colonizing aphids occurred earlier, even up to 2 weeks, than flights of potato-colonizing aphids (Fig. 1).

Table 1 Number of colonizing and non-colonizing aphids and number of Myzus persicae caught on potato leaves (sum of 1000 leaves) and in yellow water traps (average of two traps) in each year between 1 May and 31 August - total per season, absolute values in the specimens

\begin{tabular}{|c|c|c|c|c|c|c|}
\hline \multirow[t]{2}{*}{ Year } & \multicolumn{2}{|c|}{ Colonizing aphids $^{\mathrm{a}}$} & \multicolumn{2}{|c|}{ Non- colonizing aphids ${ }^{\mathrm{b}}$} & \multicolumn{2}{|c|}{ M. persicae } \\
\hline & On plants & In traps \pm SD & On plants & In traps \pm SD & On plants & In traps $\pm \mathrm{SD}$ \\
\hline 2010 & 261 & $5.5 \pm 0.2$ & 10 & $139.5 \pm 3.8$ & 39 & $5.5 \pm 0.2$ \\
\hline 2011 & 358 & $14.0 \pm 0.6$ & 3 & $298.5 \pm 8.5$ & 58 & $13.0 \pm 0.6$ \\
\hline 2012 & 1443 & $50.5 \pm 1.4$ & 12 & $934.5 \pm 24.0$ & 48 & $41.5 \pm 1.3$ \\
\hline 2013 & 32 & $21.5 \pm 0.6$ & 4 & $603.0 \pm 15.6$ & 11 & $20.5 \pm 0.6$ \\
\hline Total & 2194 & 91.5 & 29 & 1975.5 & 156 & 80.5 \\
\hline
\end{tabular}

\footnotetext{
${ }^{a}$ Aphids for which potato is a host plant (A. nasturtii and M. persicae)

${ }^{\mathrm{b}}$ Aphids for which potato is not a host plant, but alight in potato crops

$S E$ Standard deviation for the number of aphids per trap
} 
Table 2 Species of non-colonizing aphids and number of aphids per species found in the yellow water traps in 2010-2013 between 1 May and 31 August-total per season, absolute values in the specimens

\begin{tabular}{|c|c|c|c|c|c|}
\hline \multirow[t]{2}{*}{ Species } & \multicolumn{5}{|c|}{ Number of aphids per species } \\
\hline & 2010 & 2011 & 2012 & 2013 & Total \\
\hline Aphis fabae & 0.0 & 0.0 & 420.0 & 10.0 & 430.0 \\
\hline Hayhurstia atriplicis & 18.0 & 63.0 & 12.0 & 268.5 & 361.5 \\
\hline Cavariella aegopodii & 3.0 & 5.0 & 121.5 & 0.0 & 129.5 \\
\hline Brevicoryne brassicae & 52.5 & 26.5 & 20.5 & 8.0 & 107.5 \\
\hline Cryptomyzus galeopsidis & 0.5 & 49.5 & 18.0 & 33.0 & 101.0 \\
\hline Brachycaudus helichrysi & 0.5 & 17.5 & 64.0 & 0.0 & 82.0 \\
\hline Rhopalosiphum padi & 4.5 & 11.5 & 21.0 & 14.5 & 51.5 \\
\hline Drepanosiphum platanoides & 0.0 & 0.5 & 44.5 & 0.0 & 45.0 \\
\hline Metopolophium dirhodum & 2.0 & 1.0 & 32.5 & 2.0 & 37.5 \\
\hline Acyrthosiphon pisum & 3.5 & 4.0 & 0.5 & 28.0 & 36.0 \\
\hline Rhopalosiphum insertum & 6.0 & 10.5 & 9.0 & 9.5 & 35.0 \\
\hline Hyperomyzus lactucae & 3.5 & 11.0 & 6.5 & 4.5 & 25.5 \\
\hline Capitophorus hippophaes & 0.5 & 2.0 & 4.0 & 13.0 & 19.5 \\
\hline Hyperomyzus pallidus & 1.0 & 8.0 & 4.0 & 3.5 & 16.5 \\
\hline Cavariella theobaldii & 0.0 & 0.5 & 11.0 & 0.5 & 12.0 \\
\hline Capitophorus carduinus & 1.0 & 3.0 & 0.0 & 7.5 & 11.5 \\
\hline Nasanovia ribisnigri & 0.5 & 1.5 & 4.0 & 0.0 & 6.0 \\
\hline Cryptomyzus ribis & 1.0 & 0.0 & 0.0 & 4.0 & 5.0 \\
\hline Phorodon humuli & 0.5 & 0.0 & 4.0 & 0.5 & 5.0 \\
\hline Sitobion avenae & 1.0 & 0.0 & 1.0 & 3.0 & 5.0 \\
\hline Aphis craccivora & 0.0 & 1.5 & 0.5 & 1.0 & 3.0 \\
\hline Amphorophora rubi & 1.0 & 1.0 & 0.0 & 0.0 & 2.0 \\
\hline Cavariella pastinacea & 0.0 & 1.5 & 0.0 & 0.0 & 1.5 \\
\hline Aphis idaei & 0.0 & 0.0 & 0.5 & 0.0 & 0.5 \\
\hline Phorodon cannabis & 0.0 & 0.0 & 0.5 & 0.0 & 0.5 \\
\hline
\end{tabular}

\section{PVY}

In the group of cultivars that were extremely resistant (grade 9) to PVY, no PVY infections were recorded during the entire investigation period (Table 3). Only in 1 year, single plants of cultivar Stasia were infected, but this finding was not confirmed in subsequent years. Among grade 7 cultivars, the infection level was very low-in the range from 0 to $5.4 \%$. Only cv. Gawin seemed to be more resistant than was previously assumed, since no PVY was recorded in the tested tubers over the course of three consecutive years. The next group comprised susceptible cultivars of grade 5-6, among which the cultivars Etola and Viviana were rapidly infected; the percentage tubers infected with PVY after 3 years was 72.3 and 98.9\%, respectively. The very susceptible cultivars were mainly Dutch cultivars, two of which (Hermes and Sylvana) have not 

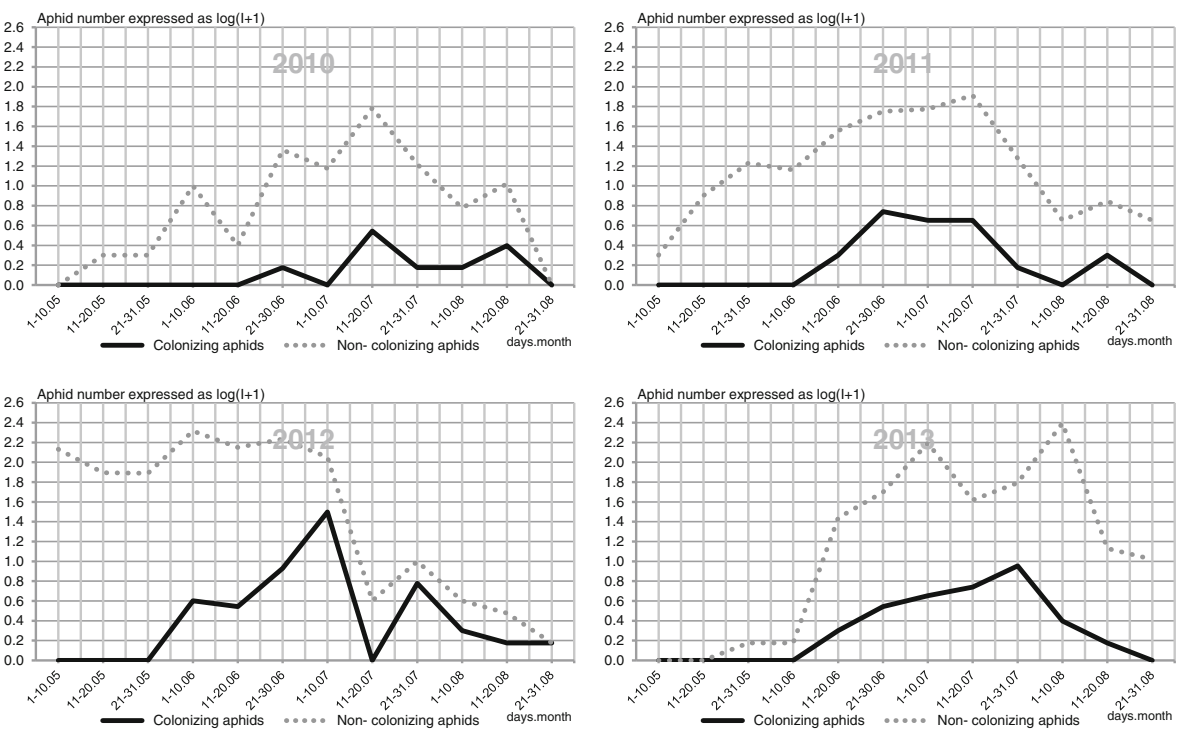

Fig. 1 Dynamics of colonizing and non-colonizing aphids catched in yellow water traps between 1 May and 31 August in the years 2010-2013

been assessed for their resistance to viruses under Polish conditions. During 2 years of the study, as many as $100 \%$ of the tubers were infected with the virus.

\section{PVM}

In the field research, the greatest susceptibility to PVM was found in cultivars Danuta and Stasia, of which over $50 \%$ of the tubers were infected after 3 years of multiplication (Table 4) despite only moderate pressure from the virus during the study period. In cultivars Altesse, Gawin, Gwiazda, Hermes, Jurata, Michalina, and Sylvana, 25\% of the tubers were infected, which classifies them as susceptible to PVM (Table 5). Cultivars Zenia, Etiuda, Jubilat, and Viviana were found to be very resistant to PVM, as the percentage of tubers infected by the virus after 3 years did not exceed $5 \%$. No PVM was detected in the tubers of cultivars Bursztyn, Gustaw, and Legenda.

\section{PLRV}

Most of the assessed cultivars were not infected by PLRV, especially those whose resistance was above 5-6 (Table 6). Cultivar Jubilat was the only exception, as $42.3 \%$ of its tubers were strongly infected in the third year. However, for this cultivar, only 52 tubers were assessed in the third year out of the original 100 planted in the first year because other tubers were lost due to rot. Among the cultivars that were most susceptible to PLRV (grade 3-4), some were not infected (for instance, Bursztyn), whereas in the case of cv. Hermes, as much as $40 \%$ of the tubers became infected in Poland. Cultivar Michalina, which was planted with a $20 \%$ virus load, showed an increase in the infection level of its tubers to nearly $100 \%$, although in the first year no increase in infection level was recorded. 
Table 3 Percentage of tubers infected by PVY in successive years of reproduction

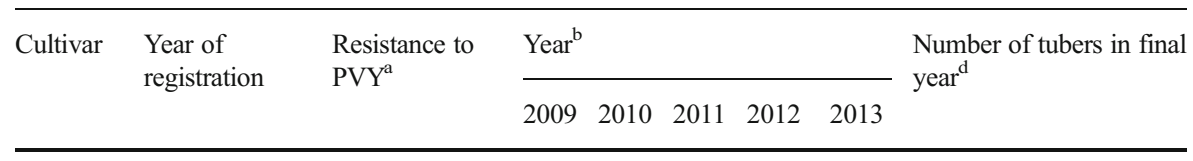

\begin{tabular}{|c|c|c|c|c|c|c|c|c|}
\hline Bursztyn & 2010 & $9 R y$ & 0.0 & 0.0 & 0.0 & 0.0 & & 67 \\
\hline Danuta & 2009 & $9 R y$ & 0.0 & 0.0 & 0.0 & 0.0 & & 98 \\
\hline Gustaw & 2010 & $9 R y$ & 0.0 & 0.0 & 0.0 & 0.0 & & 62 \\
\hline Legenda & 2010 & $9 R y$ & 0.0 & 0.0 & 0.0 & 0.0 & & 75 \\
\hline Stasia & 2010 & 8 & 0.0 & 2.1 & 0.0 & 0.0 & & 47 \\
\hline Zenia & 2010 & $9 R y$ & 0.0 & 0.0 & 0.0 & 0.0 & & 84 \\
\hline Etiuda & 2011 & $9 R y$ & & 0.0 & 0.0 & 0.0 & 0.0 & 47 \\
\hline Jurata & 2011 & 8 & & 0.0 & 0.0 & 0.0 & 0.0 & 57 \\
\hline Gawin & 2010 & 7 & 0.0 & 0.0 & 0.0 & 0.0 & & 56 \\
\hline Michalina & 2010 & 7 & 2.0 & 4.5 & 3.6 & 0.0 & & 82 \\
\hline Gwiazda & 2011 & 7 & & 0.0 & 0.0 & 0.0 & 5.4 & 92 \\
\hline Hubal & 2011 & 7 & & 0.0 & 1.0 & 0.0 & 4.3 & 92 \\
\hline Jubilat & 2011 & 7 & & 1.4 & 0.0 & 0.0 & 0.0 & 52 \\
\hline Etola & 2009 & $5-6$ & 25.3 & 35.4 & 72.3 & & & 94 \\
\hline Etola & 2009 & $5-6$ & & 0.0 & 15.1 & & & 86 \\
\hline Viviana & 2010 & $5-6$ & 1.0 & 21.6 & 68.1 & 98.9 & & 91 \\
\hline Altesse & 2009 & $3-4$ & 0.0 & 15.5 & 73.7 & 100.0 & & 96 \\
\hline Ingrid & 2009 & $3-4$ & 0.0 & 22.1 & 95.4 & 100.0 & & 66 \\
\hline Hermes & - & $3-4^{c}$ & & 0.0 & 29.0 & 100.0 & 100.0 & 88 \\
\hline Sylvana & - & $3-4^{\mathrm{c}}$ & & 0.0 & 41.7 & 100.0 & 100.0 & 71 \\
\hline
\end{tabular}

\footnotetext{
${ }^{\text {a }}$ Resistance on a scale of $1-9(9=$ extremely resistant) according to Michalak (2015); $R y$, resistance gene according to Plich and Flis (2012)

${ }^{\mathrm{b}}$ Values in the first year indicate the base health of potato seeds (in some cases lower values of infection in successive years resulted from decreasing tuber numbers in some samples due to rot)

${ }^{\mathrm{c}}$ Lack of resistance in Polish conditions - proposed resistance rating after this research

${ }^{d}$ The number of tubers remaining after the last year of reproduction out of 100 potatoes planted in the first year of the experiment
}

\section{Discussion}

Aphids are main vectors of potato-infecting viruses. The viral infection pressure depends both on sources of infection and on presence of aphids capable to transmit viruses to new plants. During the study period, very small numbers of potatocolonizing aphids were collected in the yellow water traps. At the same time, these aphids were numerous on plants, confirming that potato is their host. Among the trapped aphids, the dominant species was M. persicae (Table 1), the numbers of which were recently reported to be decreasing by Kostiw and Robak (2013). According to these authors, A. nasturtii is currently present in greater numbers than M. persicae. Their observation is confirmed in this research. A. nasturtii was observed mainly on potato leaves, not in yellow water traps (Table 1), which suggests that this species can be 
Table 4 Percentage of tubers infected by PVM in successive years of reproduction

\begin{tabular}{|c|c|c|c|c|c|c|}
\hline \multirow[t]{2}{*}{ Cultivar } & \multirow[t]{2}{*}{ Year of registration } & \multicolumn{5}{|l|}{ Year $^{\mathrm{a}}$} \\
\hline & & 2009 & 2010 & 2011 & 2012 & 2013 \\
\hline Bursztyn & 2010 & 0.0 & 0.0 & 0.0 & 0.0 & \\
\hline Danuta & 2009 & 0.0 & 10.3 & 40.0 & 68.4 & \\
\hline Gustaw & 2010 & 0.0 & 0.0 & 0.0 & 0.0 & \\
\hline Legenda & 2010 & 2.2 & 0.0 & 0.0 & 0.0 & \\
\hline Stasia & 2010 & 7.3 & 11.7 & 22.4 & 59.6 & \\
\hline Zenia & 2010 & 3.1 & 1.0 & 1.2 & 1.2 & \\
\hline Etiuda & 2011 & & 0.0 & 0.0 & 0.0 & 0.0 \\
\hline Jurata & 2011 & & 0.0 & 12.5 & 41.7 & 47.4 \\
\hline Gawin & 2010 & 1.0 & 1.0 & 6.9 & 32.1 & \\
\hline Michalina & 2010 & 0.0 & 0.0 & 3.6 & 26.8 & \\
\hline Gwiazda & 2011 & & 13.0 & 12.2 & 24.5 & 27.2 \\
\hline Hubal & 2011 & & 2.0 & 3.1 & 12.5 & 14.1 \\
\hline Jubilat & 2011 & & 6.8 & 0.0 & 0.0 & 0.0 \\
\hline Etola & 2009 & 2.0 & 7.1 & 10.6 & & \\
\hline Etola & 2009 & & 0.0 & 7.0 & & \\
\hline Viviana & 2010 & 1.0 & 1.0 & 2.2 & 4.4 & \\
\hline Altesse & 2009 & 1.0 & 5.2 & 8.1 & 25.0 & \\
\hline Ingrid & 2009 & 1.0 & 5.9 & 9.2 & 19.7 & \\
\hline Hermes & - & & 0.0 & 2.0 & 20.8 & 28.4 \\
\hline Sylvana & - & & 0.0 & 8.3 & 37.5 & 47.9 \\
\hline
\end{tabular}

\footnotetext{
${ }^{a}$ Values in the first year indicate the base health of potato seeds (in some cases lower values of infection in successive years resulted from decreasing tuber numbers in some samples due to rot)
}

currently the most important potato-colonizing aphid and thus it is probably the main vector of potato viruses. The number of non-potato-colonizing aphids was high in traps but very low on plants, confirming that potato is not their host. However, their flights may occur even 2 weeks earlier than flights of potato-colonizing aphids (Fig. 1). During

Table 5 Classification of potato cultivars according to their PVM resistance

\begin{tabular}{ll}
\hline Resistance class & Cultivars \\
\hline Very susceptible $\left(>50 \%{ }^{\mathrm{a}}\right)$ & Danuta, Stasia \\
Susceptible $(20-50 \%)$ & Altesse, Gawin, Gwiazda, Hermes, Jurata, Michalina, Sylvana \\
Fairly susceptible $(10-19.9 \%)$ & Etola, Hubal, Ingrid \\
Fairly resistant $(5-9.9 \%)$ & \\
Resistant $(<5 \%)$ & Burstyn $^{\mathrm{b}}$, Etiuda $^{\mathrm{b}}$, Gustaw $^{\mathrm{b}}$, Jubilat, Legenda \\
\end{tabular}

\footnotetext{
${ }^{\text {a }}$ Percentage of tubers infected by PVM after 3 years of reproduction

${ }^{\mathrm{b}}$ Cultivars, which have the $R m$ resistance gene according to Michalak and Wasilewicz-Flis (2013), Michalak (2015)
} 
Table 6 Percentage of tubers infected by PLRV in successive years of reproduction

\begin{tabular}{|c|c|c|c|c|c|c|c|}
\hline \multirow[t]{2}{*}{ Cultivar } & \multirow[t]{2}{*}{ Registration year } & \multirow[t]{2}{*}{ Resistance to PLRV ${ }^{a}$} & \multicolumn{5}{|l|}{ Year $^{\mathrm{b}}$} \\
\hline & & & 2009 & 2010 & 2011 & 2012 & 2013 \\
\hline Gustaw & 2010 & 7 & 0.0 & 0.0 & 0.0 & 0.0 & \\
\hline Stasia & 2010 & 7 & 0.0 & 0.0 & 0.0 & 0.0 & \\
\hline Gawin & 2010 & 7 & 0.0 & 0.0 & 0.0 & 0.0 & \\
\hline Gwiazda & 2011 & 7 & & 0.0 & 1.0 & 0.0 & 0.0 \\
\hline Sylvana & & $7^{\mathrm{c}}$ & & 0.0 & 0.0 & 0.0 & 0.0 \\
\hline Danuta & 2009 & $5-6$ & 0.0 & 0.0 & 0.0 & 0.0 & \\
\hline Legenda & 2010 & $5-6$ & 0.0 & 0.0 & 0.0 & 0.0 & \\
\hline Etiuda & 2011 & $5-6$ & & 0.0 & 2.1 & 0.0 & 0.0 \\
\hline Jurata & 2011 & $5-6$ & & 0.0 & 0.0 & 0.0 & 0.0 \\
\hline Hubal & 2011 & $5-6$ & & 0.0 & 3.1 & 3.1 & 9.8 \\
\hline Jubilat & 2011 & $5-6$ & & 0.0 & 0.0 & 3.8 & 42.3 \\
\hline Etola & 2009 & $5-6$ & 0.0 & 0.0 & 0.0 & & \\
\hline Etola & 2009 & $5-6$ & & 0.0 & 0.0 & & \\
\hline Viviana & 2010 & $5-6$ & 0.0 & 0.0 & 0.0 & 0.0 & \\
\hline Ingrid & 2009 & $5-6$ & 1.0 & 0.0 & 0.0 & 0.0 & \\
\hline Bursztyn & 2010 & $3-4$ & 0.0 & 0.0 & 0.0 & 0.0 & \\
\hline Zenia & 2010 & $3-4$ & 5.1 & 0.0 & 29.4 & 10.7 & \\
\hline Michalina & 2010 & $3-4$ & 20.0 & 20.5 & 83.3 & 96.3 & \\
\hline Altesse & 2009 & $3-4$ & 0.0 & 0.0 & 11.1 & 45.8 & \\
\hline Hermes & & $3-4^{\mathrm{c}}$ & & 0.0 & 30.0 & 39.6 & 37.5 \\
\hline
\end{tabular}

\footnotetext{
${ }^{\text {a }}$ Resistance on a scale of $1-9$ scale ( 9 = extremely resistant) according to Michalak (2015)

${ }^{\mathrm{b}}$ Values in the first year indicate the base health of potato seeds (in some cases lower values of infection in successive years resulted from decreasing tuber numbers in some samples due to rot)

${ }^{\mathrm{c}}$ Lack of resistance in Polish conditions - proposed resistance rating after this research
}

accidental flights, these aphids may transmit PVY, PVM, and PVS when probing a plant to check its suitability as a food source. Similar differences in dates between flights of colonizing and non-colonizing aphids were reported previously by Kostiw and Robak (2008). For this reason, non-colonizing aphids have recently acquired practical importance in transmitting non-persistent viruses like PVY, PVM, and PVS (Kostiw and Robak 2008; Verbeek et al. 2009).

PVY spread most intensively; in recent years, it has played a dominant role because of the increase in crops of foreign cultivars (mainly Dutch) susceptible to it, as well as changes in the population of virus strains (Chrzanowska et al. 2011; Wróbel and Wasik 2013). Since 2010, the spread of PVY on the experimental plots located in the north of Poland increased, reaching maximum values in susceptible cultivars in 2012 (Table 3). A similar trend was recorded for PVM (Table 4). For PLRV, only a few susceptible cultivars were clearly infected. The increase of virus incidence in the subsequent years of the research and reaching its highest value in 2012 was mainly connected with the increase in the number of aphids - virus vectors flying on to potatoes (Tables 1 and 2). 
In the group of cultivars with high resistance to PVY (grade 8 or 9 on a scale of 1-9; Table 3), six have the Ry gene (Plich and Flis 2012; Nowacki et al. 2013), meaning that they are extremely resistant to PVY, what was confirmed in this work by lack of infection during entire investigation period (Table 3 ). The high resistance of these cultivars in practice enables their long-lasting cultivation in many regions of Poland. Among grade 7 cultivars, no significant differences in the infection of tubers were recorded. In general, this group of cultivars can be considered resistant to the virus in field conditions, because under the experimental conditions with high infection pressure and lack of protection, only single cases of tubers infected with PVY were observed. Only sporadically, these infections reached 3-5\% (Table 3). General assessment of field resistance against PVY, performed by COBORU in Poland does not differentiate the resistance to particular strains of PVY. During the last decade, the genetic structure of the Polish PVY population has changed, and it was found that different PVY strains may dominate in successive years (Zimnoch-Guzowska et al. 2013). Thus, it may happen that cultivars resistant to most strains will be more susceptible to another particular strain or isolate. If such strain will dominate the population during a given vegetation season, increase in infection level may be observed for resistant cultivars. This hypothesis may explain sporadic infections observed for resistant cultivars of grade 7 in this work (Table 3). In the group of fairly susceptible cultivars (grade 5-6), cvs. Etola and Viviana were rapidly infected-similar to most PVY susceptible cultivars (grade 3-4). Cultivars Hermes and Sylvana have not earlier been assessed for their resistance to viruses under Polish conditions. Although in the Netherlands, they are considered quite resistant (Hermes - grade 7, Sylvana - 6.5 on a scale of $1-9$, where $1=$ susceptible, $9=$ resistant; Peeten et al. 2011), they were very susceptible (grade 3-4) in Poland; in 2 years, $100 \%$ of all tubers became infected with PVY, which placed them in this particular category.

Currently, there is no state-run field research in Poland assessing the resistance of new cultivars to PVM. A limited amount of research is still carried out at the Plant Breeding and Acclimatization Institute-National Research Institute by the Młochów Research Centre, but this research is mainly on the selection of cultivars that are highly resistant to PVM and on determining reactions to potential infection after mechanical infection of the plant with a strong strain of virus under glasshouse conditions (Michalak and Wasilewicz-Flis 2013). Note that among potato cultivars resistance to PVM is rare (Chrzanowska et al. 2011). According to the rate and level of infection following 3 years of field multiplication, the cultivars were divided into five classes of resistance. This classification system was previously proposed by Wróbel (2012) and was applied to group cultivars investigated in this work (Table 5). In the resistant group (Table 5), no infection was recorded for four cultivars (Table 4). These results were confirmed by the discovery of the $R m$ gene which is providing total resistance to PVM and which is present in the genotypes of these cultivars (Michalak and Wasilewicz-Flis 2013).

Results obtained in this work confirm that importance of PLRV, which used to be in the past as important as PVY (Kostiw and Robak 2009) is currently very low. The virus not only did not occur at all in resistant cultivars but was also hardly occurring in fairly susceptible cultivars (5-6). Even among susceptible cultivars (3-4), PLRV was not detected or caused significant infections only during last two seasons of investigation (Table 6). This is intriguing, because 
numerous sources of PLRV infection were planted in the vicinity of the multiplied material. This may be explained by high specialization of the PLRV in interactions with aphids. Its main vector is $M$. persicae, for which only 156 specimens were recorded on plants among 2194 specimens of potato-colonizing aphids (Table 1). Thus, while the infection sources were present, the low number of $M$. persicae will have been responsible for lack or low infection spread of PLRV. This corresponds well to data reported by Kostiw and Robak (2010) and Kostiw (2013a, b). In these works, authors also observed lack of infection of susceptible cultivars by PLRV despite the presence of infection sources and they connected this to a decreasing number of $M$. persicae. These earlier reported data taken together with results presented in this work suggests that the lowering importance of PLRV strictly follows the constant decline in the number of M. persicae observed during the last three decades (Kostiw 2013a). As for other viruses, also for PLRV, the resistance level determined elsewhere not always can be confirmed in Polish conditions. That was the case with the cv. Hermes, which was ranked as quite resistant in the Netherlands, but in this report due to significant infection, it was rated as susceptible (grade 3-4) in Poland.

\section{Conclusions}

Cultivar Gawin seems to be more resistant to PVY than was previously assumed. In addition, cvs. Hermes and Sylvana, which were assessed as quite resistant in the Netherlands, were evaluated as very susceptible cultivars with grade 3-4 under the conditions in this work.

The greatest susceptibility to PVM was found in cvs. Danuta and Stasia, while cvs. Zenia, Etiuda, Jubilat and Viviana were very resistant to PVM. No PVM was recorded in the tubers of cvs. Bursztyn, Gustaw, and Legenda, which additionally confirmed the presence of the resistance gene $R m$.

In tubers of cv. Bursztyn that is susceptible to PLRV (grade 3-4), no PLRV was found during the entire investigation period, which may suggest greater field resistance than grade 3-4; by contrast, cv. Hermes, assessed in the Netherlands as quite resistant to PLRV, had $40 \%$ of its tubers infected, classifying it as a susceptible cultivar under Polish conditions.

Acknowledgements My special thanks go to all of the technical employees of the Laboratory of Potato Seed Science in Bonin for their help, assistance, and involvement during the course of the research. I would also like to thank Prof. Michałi Kostiw and especially Dr. Krzysztof Treder for providing a critical review of the manuscript, Krystyna Żalejko for editorial comments, and Dr. Dominika Buchowska-Greaves for the English translation.

The research was funded by the Ministry of Science and Higher Education of Poland within the statutory activities.

\section{Compliance with Ethical Standards}

Conflict of Interest The author declares that he has no competing interests.

Funding This study was financed by the Ministry of Science and Higher Education of Poland within the statutory activities. 
Open Access This article is distributed under the terms of the Creative Commons Attribution 4.0 International License (http://creativecommons.org/licenses/by/4.0/), which permits unrestricted use, distribution, and reproduction in any medium, provided you give appropriate credit to the original author(s) and the source, provide a link to the Creative Commons license, and indicate if changes were made.

\section{References}

Bai Y, Nie X, Li X, Gao Y, Fan G, Zhang W, Geng H, Liu W (2010) The seed potato inspection and virus research in China. Am J Potato Res 87:112

Chikh Ali M, Maoka T, Natsuaki T, Natsuaki KT (2010) PVYNTN-NW, a novel recombinant strain of Potato virus Y predominating in potato fields in Syria. Plant Pathol 59:30-41

Chikh Ali M, Karasev AV, Furutani N, Taniguchi M, Kano Y, Sato M, Natsuaki T, Maoka T (2013) Occurrence of Potato virus Y strain PVYNTN in foundation seed potatoes in Japan, and screening for symptoms in Japanese potato cultivars. Plant Pathol 62:1157-1165

Chrzanowska M (2004) Nasilenie w występowaniu chorób wirusowych ziemniaka. Ochr Rośl 7(8):25-28

Chrzanowska M (2009) Rosnące zagrożenie plantacji ziemniaka wirusem Y ziemniaka. Wieś Jutra 2(127):7-9

Chrzanowska M, Michalak K, Zagórska H, Szajko K (2011) Reakcja na wirusy odmian ziemniaka znajdujących się w Krajowym Rejestrze w 2010 roku (The reaction to virus infection of potato cultivars from the Polish National List in 2010). Biul IHAR 260-261:309-324

Dědič P, Ptáček J, Čeřovská N (2008) A shift of PVY spectrum in potatoes in the Czech Republic in past years. Potato Res 51:198

Gabriel W (1989) Epidemiologia chorób wirusowych ziemniaka. PWN, Warszawa

Gray S, Whitworth J, Xu H, Singh R, Karasev A (2013) The current state (2012) of Potato virus Y (PVY) affecting potato grown in North America. NAPPO Science and Technology. http://www.nappo.org/en/ data/files/download/Science_and_technology_documents/Relevant_PVY_strains_e.pdf. Accessed 17 Aug 2015

Islam AKMS, Akanda AM, Wazed MA, Chewdhery MRA, Rahman MJ (2014) Performance of fifth generation seed potato against Potato virus Y (PVY). Sch J Agric Sci 4(2):74-81

Kaczmarek U, Turska E, Hnat A (1998) The spread of PVY stains some cultivars after multiplicationin field condition, the 10th EAPR Virology Section Meeting. Baden, Austria, 5-10 July, Abstracts: 43-44

Kostiw M (1987) Przenoszenie ważniejszych wirusów ziemniaka przez mszyce. Inst Ziemn, Bonin

Kostiw M (2011) The occurrence of major potato viruses in Poland. J Plant Protect Res 51(3):205-209

Kostiw M (2013a) Nasiennictwo ziemniaka w Polsce: uwarunkowania przyrodnicze, odmianowe i rynkowe (seed potato in Poland: natural, varietal and market conditions). Biul IHAR 268:129-142

Kostiw M (2013b) Zagrożenie plantacji nasiennych ziemniaka wirusami w świetle najnowszych wyników badań. In: Nasiennictwo i ochrona ziemniaka. Abstracts of Papers and Posters, Conference, Dźwirzyno, May 16-17, ZNiOZ IHAR-PIB Bonin Poland: 42-45

Kostiw M, Robak B (2002) The spread of PVY, PVM, PVS and PLRV at Bonin conditions during 1996-1999. J Plant Protect Res 42(2):165-171

Kostiw M, Robak B (2008) Skład gatunkowy, termin migracji i dynamika liczebności mszyc „nieziemniaczanych” w uprawie ziemniaka w różnych rejonach kraju (species composition, migration period and dynamic of number of non potato colonizing aphids in different regions of Poland). Prog Plant Protect 48(3):881-888

Kostiw M, Robak B (2009) Ocena zagrożenia plantacji nasiennych ziemniaka przez wirusy Y i liściozwoju w 2009 roku. Ziemniak Polski 4:4-10

Kostiw M, Robak B (2010) Presja wirusów Y, M, S i liściozwoju ziemniaka w latach 2006-2008 w Boninie (infection pressure of PVY, PVM, PVS and PLRV in the period 2006-2008 in Bonin). Biul IHAR 256: $141-151$

Kostiw M, Robak B (2013) Presja mszyc w 2013 roku i zagrożenie plantacji nasiennych ziemniaka wirusami Y i liściozwoju. Ziemniak Polski 4:8-13

Kostiw M, Sekrecka D (2009) Infection of potato tubers of chosen cultivars by Y, M, S and Potato Leafroll Viruses in ecological crops in the North of Poland in years 2006-2008. Phytopathol Pol 51:45-52

Lindner K (2008) PVY strains in Germany — the period between 1984 and 2006. Potato Res 51:202 
Michalak K (2006) Ocena odpornosci odmian ziemniaka na wirusy w doswiadczeniach przedrejestrowych (procedure of evaluation of potato cultivars for resistance to viruses applied in Plant Breeding and Acclimatization Institute, Młochów Research Center). Prog Plant Protect 46(2):715-718

Michalak K (2015) Odporność i reakcja odmian ziemniaka na zakażenie wirusami Y, M, X i liściozwoju ziemniaka oceniona w latach 2010-2013. In: Nasiennictwo i ochrona ziemniaka. Abstracts of Papers and Posters, Conference, Dźwirzyno, May 13-15, ZNiOZ IHAR-PIB Bonin Poland: 79-81

Michalak K, Wasilewicz-Flis I (2013) Odporność na wirusy M i S w tetraploidalnych materiałach ziemniaka. Ziemniak Polski 4:4-8

Milošević D (1996) Efficacy of oil and insecticides in potato plant protection against infection by Potato virus Y and leaf roll virus (PVY and PLRV). Plant Prot 47(4):333-342

Müller FP (1966) Geflügelte Blattläuse in Gelbschalen. Wissenchaftliche Zeitschrift der Universität Rostock Matematisch Naturwissenschaftlich Reihe 2:295-313

Nowacki W, Boguszewska D, Czerko Z, Goliszewski W, Grudzińska M, Jankowska J, Lutomirska B, Pietraszko M, Trawczyński C, Wierzbicka A, Zarzyńska K, Zgórska K, Michalak K (2013) Charakterystyka Krajowego Rejestru Odmian Ziemniaka. IHAR-PIB Jadwisin

Peeten HMG, Folkertsma S, Schipper JK, Baarveld HR, van der Klein S (2011) Netherlands catalogue of potato varietes 2011. NIVAP Den Haag, Netherlands

Plich J, Flis B (2012) Hodowla odpornościowa — efektywny sposób walki z patogenami ziemniaka. Ziemniak Polski 1:8-13

Rahman MS, Akanda AM (2010) Effect of PLRV infected seed tuber on disease incidence, plant growth and yield parameters of potato. Bangladesh J Agric Res 35(3):359-366

Rahman MS, Akanda AM, Mian IH, Bhuian MKA, Karim M (2010) Growth and yield performance of different generations of seed potato as affected by PVY and PLRV. Bangladesh J Agric Res 35(1):37-50

Rolot JL, Steyer S (2008) First screenings of the different PVY strain in Belgium. Potato Res 51:204

Scholthof KBG, Adkins S, Czosnek H, Palukaitis P, Jacquot E, Hohn T, Hohn B, Saunders K, Candresse T, Ahlquist P, Hemenway C, Foster GD (2011) Top 10 plant viruses in molecular plant pathology. Mol Plant Pathol 12(9):938-954

Sigvald R (1984) The relative efficiency of some aphid species as vectors of Potato virus $\mathrm{Y}^{0}$ (PVY $\mathrm{PV}^{0}$. Potato Res 27(3):285-290

Styszko L (1993) Znaczenie odmian w nasiennictwie ziemniaka (the significance of cultivars in the seed potato production). Zesz Nauk AR Wroc 223, Rol LVIII:355-359

Świeżyński KM, Chrzanowska M, Domański L, Zimnoch-Guzowska E (2001) Comparison of resistance evaluation in potato variety assessment. Potato Res 44:25-31

Taylor LR, Palmer JMP, Dupuch MJ, Cole J, Taylor MS (1980) A handbook for the rapid identification of alate aphids of Great Britain and Europe. EURAPHID, Rothamsted

Van der Vlugt RAA, Verbeek M, Cuperus C, Piron PGM, De Haan D, Van de Bovenkamp GW (2008) Strains of Potato virus $\mathrm{Y}$ in Dutch seed potato culture. Potato Res 51:191

Verbeek M, Piron PGM, Dullemans AM, Cuperus C, van de Vlugt RAA (2009) Determination of aphid transmission efficiencies for N, NTN and Wilga strains of Potato virus Y. Ann Appl Biol 156(1):39-49

Whitworth JL, Nolte P, McIntosh C, Davidson R (2006) Effect of Potato virus Y on yield of three potato cultivars grown under different nitrogen levels. Plant Dis 90(1):73-76

Wróbel S (2012) Tempo degeneracji nowych odmian ziemniaka w warunkach naturalnych (the rate of degeneration of new potato cultivars under the field conditions). Prog Plant Protect 52(1):174-177

Wróbel S (2014a) Efficacy of mineral oil-insecticide mixtures for protection of potato tubers against PVY and PVM. Am J Potato Res 91(6):706-713

Wróbel S (2014b) Modification of ELISA by replacing incubation of microtiter plates in an incubator with their shaking in PVY, PVM and PLRV detection. Am J Potato Res 91(4):354-362

Wróbel S, Turska E (2005) Nowe odmiany ziemniaka w produkcji nasiennej (The new potato cultivars in seed production). Biul IHAR 237(238):93-98

Wróbel S, Wąsik A (2013) Seed potato production in Poland. Am J Potato Res 91(3):260-268

Zagórska H, Chrzanowska M (2007) Analiza wyników badań z lat 1973-2005 nad reakcją odmian ziemniaka na wirus M ziemniaka (Analysis of the results of studies conducted in 1973-2005 on reaction of potato cultivars to Potato virus M). Biul IHAR 243:227-233

Zimnoch-Guzowska E, Yin Z, Chrzanowska M, Flis B (2013) Sources and effectiveness of potato PVY resistance in IHAR's breeding research. Am J Potato Res 90(1):21-27 